Daniel Boćkowski (Białystok)

\title{
POLSKA - ZSRR W XX WIEKU \\ - PRZEGLĄD BIBLIOGRAFICZNY \\ ZA LATA 2000 - 2004 (WYBÓR)
}

Po raz kolejny pozwalam sobie przedstawić wybór prac dotyczących stosurików polsko-radzieckich i polsko-rosyjskich w XX wieku, a także kwestii rosyjskich w ogóle, które ukazały się od 2000 do 2004 roku. Niniejszy zakres chronologiczny podyktowany jest docieraniem do mnie niektórych książek z dość dużym opóźnieniem, a nie chcę, by pozostały one niezauważone.

Dla ułatwienia zestawienie podzieliłem na poszczególne lata. Za punkt odniesienia przy dodawaniu książki do niniejszego spisu przyjąłem podaną przez wydawnictwo datę wydania, choć wiem, że nie zawsze jest to adekwatne do faktycznego czasu ukazania się danej pozycji. Wydawnictwo podaję dla ułatwienia nabycia ewentualnej pozycji - większość wydawnictw posiada już swoje księgarnie internetowe. Zdaję sobie sprawę, że prezentowany przegląd nie jest pełny, niemniej jednak opracowanie takie powinno pomóc wielu historykom w poszukiwaniach bibliograficznych.

\section{Rok 2000}

1. Zbigniew S. Siemaszko, Poczatki sowietyzacji (1939-1946), Caldra Mouse, Londyn 2000, ss. 295. Książka ta stanowi rozwinięcie i uzupełnienie pracy tegoż autora z 1991 r. pt. „W sowieckim osaczeniu, 1939-1943” oraz kolejnej pracy z 1999 r. pt. „Świadkowie przeżyć sowieckich 1939-1946”. We wstępie autor ostro polemizuje z ukazującymi się po roku 1989 staraniem rosyjskiego „Memoriału” oraz Ośrodka Karta w Warszawie pracami, w których liczba represjonowanych obywateli polskich znacznie odbiega od tej, przyjętej przez wychodźcze środowiska emigracyjne. Bardzo interesujące są ponownie zestawiane przez autora szacunki dotyczące liczby represjonowanych, mające wykazaćbłędność i niedoskonałość źródeł radzieckich oraz potwierdzić, że obliczenia dokonane przez polską emigrację, mówiące o milionach ofiar, nadal pozostają najbardziej „zbliżonymi do prawdy”. Dal- 
sze rozdziały pracy stanowią przedruki różnych artykułów tegoż autora zamieszczonych głównie w „Zeszytach Historycznych” oraz prasie emigracyjnej w latach 1970-2000.

\section{Rok 2001}

1. Zbigniew S. Siemaszko, Pod sowieckq wtadza (1939-1942), Polska Fundacja Kulturalna, Londyn 2001, ss. 301. Książka ta to zbiór wspomnień i relacji jednego z najaktywniejszych emigracyjnych badaczy losów Polaków w ZSRR wczasie II wojny światowej z jego pobytu na zesłaniu w Kazachstanie w obwodzie pawłodarskim, w miejscowości Siemijarsk. Losy rodziny Siemaszków są dość typowe dla wszystkich polskich rodzin deportowanych do Kazachstanu w kwietniu 1940 r. Najciekawszy jest $\mathrm{w}$ nich epizod autora, którego w czasie deportacji nie zastano $\mathrm{w}$ domu, i który chcąc połączyć się z wywiezioną rodziną napisał wraz z innymi osobami znajdującymi się w podobnej sytuacji specjalny list do Stalina z prośbą o przewiezienie go do rodziny, dzięki czemu dotarł do nich na zsyłkę kilka miesięcy później. Uzupełnieniem wspomnień są trzy aneksy. Jeden z nich stanowi przedruk $\mathrm{z}$ książki $W$ sowieckim osaczeniu, drugi spis rodzin zamieszkujących $\mathrm{w}$ rejonie bieskaragajskim, trzeci - niewielkie imienne zestawienie osób, które prawdopodobnie zgładzone zostały wiosną $1940 \mathrm{r}$. w ramach tzw. listy białoruskiej, stanowiącej uzupełnienie list katyńskich.

2. „Wrocławskie Studia Wschodnie” nr 5 (2001), Wydawnictwo Uniwersytetu Wrocławskiego, Wrocław 2001, ss. 302. W numerze wart polecenia jest artykuł Stanisława Ciesielskiego pt. Prawne i organizacyjne podstawy masowych deportacji w ZSRR (1930-1952) w którym autor szczegółowo omawia procedury regulujące wysiedlanie ludności oraz wszelkie akty prawne dotyczące tych działań a także Marka Golińczaka pt. Ruch dysydencki w Zwiqzku Radzieckim w latach sześćdziesiatych $i$ siedemdziesiatych. Zarys problemu.

3. Mirosław Golon, Polityka radzieckich władz wojskowych $i$ policyjnych na Pomorzu Nadwiślańskim w latach 1945-1947, Wydawnictwo Uniwersytetu Mikołaja Kopernika, Toruń 2001, ss. 380. W pracy tej autor stara się ukazać radziecką politykę okupacyjną na terenie Polski w najgorętszym okresie utrwalania władzy ludowej i wysiedleń ludności niemieckiej. Głównym jej celem jest ukazanie walki radzieckich służb wojskowych i bezpieczeństwa z polskim podziemiem niepodległościowym oraz bezwzględna, rabunkowa eksploatacja tych ziem przez stacjonujące tam oddziały. Przykład Pomorza Nadwiślańskiego (powojenne województwa pomorskie i gdańskie) pozwala lepiej zrozumieć jak poważnym problemem ekonomicznym i politycznym dla wyzwolonej spod okupacji niemieckiej Polski była polityka ZSRR. Praca składa się z siedmiu rozdziałów. W pierwszym autor opisuje zasady i regulacje prawne sankcjonujące stacjonowanie na Pomorzu jednostek radzieckich, w drugim prowadzoną przez wojsko i organa NKWD deportację mieszkańców Pomorza Nadwiślańskiego do obozów pracy przymusowej w ZSRR na tle działalności Głównego Zarządu NKWD ZSRR ds. Jeńców Wojennych i Inter- 
nowanych w Europie środkowowschodniej w latach 1944-1945. W rozdziale trzecim zamiesza on charakterystykę deportowanych mieszkańców Pomorza Nadwiślańskiego oraz omawia główne przyczyny aresztowań i deportacji, których apogeum przypadło na rok 1945 . W rozdziale czwartym omówiona została polityka represyjna władz radzieckich wobec uczestników konspiracji niepodległościowej w latach 1945-1947, w tym deportacje żołnierzy Armii Krajowej i członków innych organizacji konspiracyjnych do obozów w głębi ZSRR. W rozdziale piątym opisane zostały losy mieszkańców Pomorza w obozach pracy Głównego Zarządu ds. Jeńców Wojennych i Internowanych NKWD ZSRR. Rozdziały szósty i siódmy opisują szczegółowo radziecką politykę wobec przemysłu, gospodarki komunalnej oraz rolnictwa. Pracę kończy bibliografia tematu oraz indeksy: osób i geograficzny.

\section{Rok 2002}

1. Wanda Krystyna Roman, Konspiracja polska na Litwie $i$ Wileńszczyźnie wrzesien 1939 - czerwiec 1941. Lista aresztowanych, Wydawnictwo Adam Marszałek, Toruń 2002, ss. 251. Książka ta jest próbą przybliżenia przez autorkę dziejów polskiej konspiracji niepodległościowej na Wileńszczyźnie w okresie od wkroczenia wojsk radzieckich we wrześniu 1939 r. do rozpoczęcia wojny niemiecko radzieckiej w czerwcu 1941 roku i zajęciach tych terenów przez oddziały Wehrmachtu, co diametralnie zmieniło nie tylko zadania polskiej konspiracji niepodległościowej, ale też sposoby i cele prowadzenia działalności podziemnej. Praca powstała w oparciu o odtajnione dokumenty radzieckich i litewskich organów bezpieczeństwa. Składa się z trzech części. W pierwszej autorka kreśli zarys dziejów konspiracji polskiej na Litwie i Wileńszczyźnie od września 1939 do czerwca $1941 \mathrm{r}$. W drugiej charakteryzuje organa represji NKWD, struktury i sposoby ich działania, sądy oraz procedury procesowe, które obowiązywały w tym czasie i na mocy których zapadały wyroki. Część trzecia pracy - to obszerna lista Polaków aresztowanych na Wileńszczyźnie i Litwie w okresie od września 1939 do czerwca 1941 r. Dodatkowo praca zawiera aneks z wykazem Polaków przebywających w więzieniu wileńskiego NKGB 10 maja 1941 r. Całość zaopatrzona została w selektywną bibliografię oraz indeks nazwisk i pseudonimów.

2. „Wrocławskie Studia Wschodnie” nr 6 (2002), Wydawnictwo Uniwersytetu Wrocławskiego, Wrocław 2002 , ss. 337. Numer prawie w całości poświęcony problematyce rosyjskiej. Stanisław Ciesielski w artykule GUŁag w radzieckim systemie represji (do 1941 r.) charakteryzuje powstanie rozwój i sposób funkcjonowania radzieckiego „łagrowego imperium” od 1918 roku. Swoistym uzupełnieniem tego tekstu są dwa artykuły Grzegorza Hryciuka: Warunki życia w poprawczych obozach pracy Gutag OGPU (NKWD) w świetle „Regulaminu poprawczych obozów pracy" $z 1930$ r. $i$ „Tymczasowej instrukcji o reżimie przetrzymywania więzniów w ITE NKWD ZSRR" z 1939 r. oraz Bunty i strajki w radzieckich obozach specjalnych w latach 1953-1954 - Norylsk, Workuta, Kengir. Małgorzata Ruchniewicz w tekście Polski w radzieckich więzieniach i obozach w latach 1944-1956 
ukazuje nam pogmatwane losy polskich kobiet zatrzymanych przez NKWD i NKGB i skazanych na wieloletni pobyt w łagrach za działalność konspiracyjno-niepodległościową na rzecz państwa polskiego. Stanisław Ciesielski w artykule Centralny zarzqd systemu obozowe go OGPU-NKWD-MWD ZSRR w latach 1930-1960 i jego naczelnicy $\mathrm{w}$ krótkich notach biograficznych przybliża nam postacie „władców łagrowego imperium", z których wielu zostało rozstrzelanych w wyniku kolejnych reorganizacji struktur bezpieczeństwa. Ostatnim z wartych tu odnotowania jest artykuł Sławomira Kalbarczyk Obywatele polscy w sowieckich obozach pracy poprawczej w latach 1939-1945. Próba oceny dorobku historiografii minionego dziesięciolecia, problemy, postulaty badawcze.

\section{Rok 2003}

1. Deportowani w obwodzie archangielskim, częśé 1, Alfabetyczny wykaz 9320 obywateli polskich wywiezionych $w 1940$ roku z obwodu biatostockiego, Indeks Represjonowanych, tom XIV, Centrum Informacji Urzędu Spraw Wewnętrznych Obwodu Archangielskiego w Archangielsku, Ośrodek Badań, Informacji i Upowszechniania „Memoriał” w Moskwie, Ośrodek Karta w Warszawie, Warszawa 2003 , ss. 815 . Jest to pierwszy tom zawierający wykazy imienne osób deportowanych w głąb ZSRR z północno-wschodnich ziem Polski w okresie okupacji radzieckiej 1939-1941, opracowany na podstawie przechowywanych w Centrum Informacji Urzędu Spraw Wewnętrznych Obwodu Archangielskiego materiałów operacyjnych wytworzonych przez organa NKWD obwodu archangielskiego odpowiedzialne za „opiekę” nad obywatelami polskimi zsyłanymi na teren obwodu w lutym i czerwcu $1940 \mathrm{r}$. Wykaz nazwisk poprzedza opracowanie Aleksandra Gurianowa z rosyjskiego „Memoriału” opisujące sytuację obwodu białostockiego w okresie 1939-1941 oraz procedury i przebieg akcji deportacyjnych, w wyniku których do obwodu skierowano dziesiątki tysięcy polskich obywateli z całej tzw. Zachodniej Białorusi i Zachodniej Ukrainy. W pracy znajdują się także dwa ważne aneksy: wykaz kolejowych transportów deportacyjnych do obwodu archangielskiego oraz katalog specposiołków obwodu archangielskiego.

2.Aresztowani na „Zachodniej Biatorusi”, Alfabetyczny wykaz 4669 Polaków i obywateli polskich innych narodowości aresztowanych na „Zachodniej Biatorusi" w latach 1939-1941, Indeks Represjonowanych, tom XV, Archiwum Historii Najnowszej - Stowarzyszenie „Dyjariusz” w Mińsku, Ośrodek Karta w Warszawie, Warszawa 2003, ss. 380. Tom ten zawiera dane o osobach aresztowanych i skazanych na terenach północno-wschodnich województw II RP zajętych po 17 września 1939 r. przez ZSRR i wcielonych do Białoruskiej SRR. Biogramy pochodzą z Archiwum Historii Najnowszej prowadzonego przez Stowarzyszenie „Dyjariusz" w Mińsku, gdzie znajduje się skomputeryzowana kartoteka osób podlegających rehabilitacji, powstała kilka lat wcześniej w Głównym Zarządzie Archiwów Białorusi na podstawie kartoteki ewidencyjnej osób zrehabilitowanych z Archiwum KGB w Mińsku, opracowanej w oparciu o dokumenty przetrzymywane w archiwach 
obwodowych w Brześciu, Witebsku, Mohylewie, Homlu, Grodnie i Mińsku. Całość poprzedza wstęp Sławomira Kalbarczyka opisujący powstanie i działalność polskiego ruchu oporu na tych ziemiach oraz zwalczanie go przez organa NKWD i NKWGB.

3. Dariusz Rogut, Polacy $z$ Wileńszczyzny $w$ obozach sowieckich „saratowskiego szlaku” (1945-1949), Wydawnictwo Adam Marszałek, Toruń, 2003, ss. 415. W pracy tej przedstawione zostały losy Polaków aresztowanych przez NKWD i NKGB po zajęciu Wileńszczyzny w 1944 roku pod zarzutem współpracy lub przynależności do AK, organizacji - z punktu widzenia Kremla - wrogiej wobec ZSRR, stawianej na równi z wojskami hitlerowskimi. Ludzi tych wywieziono w marcu i maju 1945 r. do obozów pracy poprawczej na tzw. „saratowskim szlaku”. W kolejnych rozdziałach autor szczegółowo omawia przebieg aresztowań i ich zasięg, pobyt tych ludzi w obozach kontrolno-filtracyjnych w Jełszance k. Saratowa i Kutaisi, gdzie zostali poddani wstępnemu śledztwu, mającemu ustalić zakres ich winy, a następnie ich losy w obozach dla jeńców wojennych i internowanych w Stalingradzie, Astrachaniu i Borowiczach, z których (niestety nie wszyscy) zwolnieni zostali dopiero na przełomie 1948 i 1949 r. Praca zawiera wiele bardzo ciekawych fotokopii dokumentów, szkiców, rysunków sytuacyjnych, map i zdjęć z badanego okresu. Kończy ją obszerna bibliografia tematu, liczneaneksy, indeks nazwisk oraz streszczenia w języku angielskim i rosyjskim.

4. Jerzy R. Prochwicz, Formacje Korpusu Ochrony Pogranicza w 1939 roku, Wydawnictwo Neriton, Warszawa 2003, ss. 458. Autor niniejszej pracy jest wybitnym znawcą tej problematyki, badającym historię KOP od wielu lat. W omawianej tu książce przybliża nam ostatni, najbardziej gorący rok istnienia tej formacji, zakończony bohaterskimi walkami tych żołnierzy zarówno z wojskami niemieckimi, jak i sowieckimi. W rozdziale I pracy opisuje szczegółowo organizację i rolę KOP w systemie obronnym II RP do końca marca 1939 r. Rozdział II stanowi rozwinięcie poruszanej wcześniej problematyki i dotyczy działalności KOP w okresie narastającego zagrożenia wojennego - przygotowania wojenne, mobilizację, tworzeni jednostek liniowych na bazie pododdziałów KOP, dyslokację i stan organizacyjny KOP w dniu 31 sierpnia 1939 r. Rozdział III i IV poświęcony jest walkom jednostek KOP na froncie zachodnim z Niemcami od 1 do 9 i od 10 do 16 września 1939 r. Dwa kolejne rozdziały dotyczą historii zmagań KOP z wielokrotnie silniejszą Armią Czerwoną od 17 września 1939 r. - walki o strażnice w pasie działania poszczególnych frontów, walki odwrotowe w północno-wschodniej Polsce, działania Zgrupowania KOP na Polesiu, Lubelszczyźnie, Wołyniu i Podolu. Rozdział VII poświęcony jest ostatnim walkom żołnierzy KOP w obronie Półwyspu Helskiego, we Lwowie, na Lubelszczyźnie i pod Kockiem. Pracę kończą 34 aneksy, obszerna bibliografia tematu oraz indeksy: osób i geograficzny.

5. Joanna Gierowska-Kałłaur, Zarzqd Cywilny Ziem Wschodnich (19 lutego 1919 - 9 września 1920), Wydawnictwo Neriton, Instytut Historii PAN, Warszawa 2003 , ss. 447. Praca ta stanowi zwieńczenie wieloletnich badań autorki oraz jej kwerend w archiwach i bibliotekach litewskich. Jej tematem jest mało znany w polskiej historii epizod, jakim było powołanie i działalność Zarządu Cywilnego Ziem 
Wschodnich, stanowiącego niezwykle ważny element w procesie kształtowania się polskiej państwowości. Książka składa się z dziewięciu rozdziałów chronologicznie opisujących nam sytuację panującą w tym czasie na ziemiach wschodnich dawnej Rzeczypospolitej. W rozdziale pierwszym dowiadujemy się o ogólnej sytuacji panującej w Polsce i na Litwie w chwili odzyskiwania przez Polskę niepodległości; w rozdziale drugim pokazany został proces tworzenia się, rozwoju u zamierania struktur Zarządu Cywilnego Ziem Wschodnich od 8 lutego 1919 do 9 września 1920 r. W rozdziale trzecim przybliżony nam został skład osobowy Zarządu Cywilnego, w rozdziale czwartym stosunek do niego Naczelnego Dowództwa Wojsk Polskich. W rozdziale piątym autorka ukazuje rolę Sejmu Ustawodawczego w kształtowaniu polityki polskiej wobec ziem podległych jurysdykcji Zarządu. W kolejnych rozdziałach omówione zostały m.in.: szkolnictwo na ziemiach podległych Zarządowi Cywilnemu, program ZCZW w odniesieniu do Litwy i Białorusi a także historia powstania i rozwoju ZCZW w okręgu wołyńskim. Całość kończy obszerna bibliografia oraz indeks osób. Minusem jest brak indeksu geograficznego, który przy tego typu pracach wydaje się rzeczą niezbędną.

6. Wojsko Polskie w ZSRR $w 1943$ roku wobec powstajacego systemu wtadzy. Udziat 1. Dywizji Piechoty im. Tadeusza Kościuszki w bitwie pod Lenino, red. naukowa Stefan Zwoliński, Wydawnictwo Neriton, Warszawa 2003, ss. 213. Praca ta w nowatorski sposób opisuje znaną powszechnie historię bitwy pod Lenino. W rozdziale pierwszym pracy, autorstwa Stefana Zwolińskiego, omówiony został radziecki plany wojny z III Rzeszą oraz podejmowane przez ZSRRjuż latem 1940 r. pierwsze próby utworzenia polskiej dywizji w składzie Armii Czerwonej, a także analogiczne plany Sikorskiego, które przedstawił on stronie brytyjskiej po klęsce Francji. W rozdziale drugim, tegoż samego autora, omówione zostały konsekwencje powstania w ZSRR polskiej dywizji piechoty, jako dowodu na zmianę stanowiska Kremla, co do powojennych losów ziem polskich. Rozdział trzeci, autorstwa Stanisława Jaczyńskiego, przedstawia w zupełnie nowym świetle naszą wiedzę na temat przygotowań, przebiegu i konsekwencji bitwy pod Lenino, która nie jest już bohaterskim starciem Polaków ramię w ramię z żołnierzami radzieckimi, a raczej bezsensowną rzezią żołnierzy, którym polecono szturmować bez przygotowania doskonale umocnione wzgórza nie mające w tym czasie praktycznie żadnego znaczenia strategicznego. Książkę kończy rozdział autorstwa Stefana Zwolińskiego omawiający nastroje w Korpusie PZS w ZSRR wobec powstającego nowego systemu władzy. Całość zamyka obszerny zbiór aneksów (31 dokumentów), wśród których jednymi z najciekawszych są: opis działań bojowych 1 DP sporządzony przez Z. Berlinga oraz list Berlinga do pełnomocnika rządu radzieckiego ds. formowania się Wojska Polskiego w ZSRR gen. mjr. G. S. Żukowa w sprawie okoliczności użycia $1 \mathrm{DP}$ w bitwie pod Lenino. Pracę zamyka bibliografia tematu oraz indeksy: osobowy i miejscowości.

7. Alicja Paczoska, Dzieci Jatty. Exodus ludności polskiej z Wileńszczyzny w latach 1944-1947, Wydawnictwo Adam Marszałek, Toruń 2003, ss. 425. Książka ta przedstawia dzieje dziesiątek tysięcy ludzi, którzy w latach 1944-1947 musieli opuścić strony ojczyste, wyrzec się historii i tradycji swych przodków i udać w nie- 
znane. Składa się z pięciu rozdziałów. W rozdziale pierwszym omówiona została sytuacja Polaków na ziemiach północno-wschodnich II RP w czasie II wojny światowej w ujęciu chronologicznym: „pierwszego sowieta” (18 września - 29 października 1939 r.), przynależności Wilna do Litwy (28 października 1939 - 15 czerwca 1940 r.), okresu istnienia Litewskiej SRR (15 czerwca 1940 - 22 czerwca 1941), lat okupacji niemieckiej i ponownego zajęcia tych terenów przez wojska radzieckie. W rozdziale drugim autorka omawia prawno-międzynarodowe podstawy przesiedleń ludności polskiej osadzając je w historycznym kontekście wieloletniego konfliktu pomiędzy Polską i Litwą o to miasto. W rozdziale trzecim przedstawione zostały przygotowania do przesiedleń - organizacja punktów repatriacyjnych, organizacja przesiedleń osób poszukiwanych przez NKWD. Rozdział czwarty w całości poświęcony jest przebiegowi akcji repatriacyjnej: organizowaniu transportów, przygotowaniach do drogi, wywożeniu mienia i dóbr kultury, podróży, przekraczaniu granicy, warunkom życiowym w wagonach i na stacjach docelowych, gdzie ludzie ci poddawani byli rejestracji. W ostatnim rozdziale opisane zostały pierwsze miesiące pobytu na nowym miejscu (rola PUR, kłopoty z asymilacją, obcość i wrogość otoczenia), polityka osadnicza oraz represje, jakie dosięgły osób uznanych przez nowe władze za stanowiące zagrożenia dla interesów państwa. Pracę zamyka obszerna bibliografia tematu i aneksy. Niestety praca nie posiada żadnych indeksów, co znacząco obniża jej wartość.

8. Historycy polscy, litewscy i białoruscy wobec problemów XX wieku. Historiografia polska, litewska i biatoruska po 1989 roku, Instytut Historii Uniwersytetu w Białymstoku, Archiwum Państwowe w Białymstoku, Białystok 2003, ss. 152. Książka ta stanowi pokłosie konferencji o tym samym tytule, jaka odbyła się w Białymstoku w 2002 roku w ramach tematu „Wspólne dziedzictwo ziem północno-wschodnich dawnej Rzeczypospolitej”. Do najbardziej nas interesujących zaliczyć można artykuły: Zofii Tomczonek Badania nad Kresami PótnocnoWschodnimi Drugiej Rzeczypospolitej w polskiej historiografii, Wojciecha Śleszyńskiego Dzieje okupacji sowieckiej 1939-1941 w najnowszej historiografii polskiej, Eugeniusza Mironowicza Ruch partyzancki na Biatorusi w historiografii biatoruskiej i polskiej, Algisa Kasperaviciusa Wspótcześni historycy litewscy o sprawie Wilna i stosunkach polsko-litewskich latach 1918-1940 oraz zmianach w potocznej świadomości Litwinów.

9. Tadeusz Nasierowski, Z czarta kuźni rodem... Psychiatria, psychologia i fizjologia sowiecka w pierwszych latach po rewolucji, Wydawnictwo Neriton, Warszawa 2003, ss. 327. Nieco inna, ale także niezwykle interesująca praca, traktująca o początkach psychiatrii radzieckiej i jej ogromnym wpływie zarówno na losy badaczy, jak i radzieckich dysydentów. Psychiatria od zawsze traktowana była w Rosji carskiej a potem bolszewickiej jako coś innego, obcego, a przynajmniej dziwnego, co nie przeszkadzało władzom podejmować prób (wówczas jeszcze nieśmiałych) wykorzystania nauki i jej możliwości dla własnych potrzeb (zwłaszcza wykorzystywania szpitali psychiatrycznych do przetrzymywania tam więźniów). Praca składa się z czterech części. Dwie pierwsze niejako wprowadzają nas w specyficzny klimat rosyjskiej psychiatrii. Mamy tu fenomen Pawlika Morozowa, sprawę Alek- 
sandra Sołżenicyna i Andrzeja Sacharoza oraz w wyjątkowo ciekawy sposób przestawioną sprawę Marii Spirydonowej. W części trzeciej autor omawia historię pierwszych lat psychiatrii radzieckiej po przewrocie bolszewickim, jej wzloty i upadki, kłopoty z dostosowaniem się do nowej rzeczywistości oraz fatalną sytuację aprowizacyjno-bytową rosyjskich szpitali psychiatrycznych, pozbawionych praktycznie wszystkiego, z żywnością i opałem na zimę. W części trzeciej, zatytułowanej dość przewrotnie „Dialektywizacja biologii - pułapka ideologicznej poprawności” autor opisuje nam dzieje kilku wybitnych rosyjskich psychiatrów. Pracę kończy aneks, w którym omówiona m.in. został rola staroobrzędowców w dziejach Rosji, obszerna bibliografia tematu oraz indeks nazwisk.

10. Z dziejów Polski i emigracji (1939-1989). Księga dedykowana bytemu Prezydentowi Rzeczypospolitej Polskiej Ryszardowi Kaczorowskiemu, pod red. Marka Szczerbińskiego i Tadeusza Wolszy, Instytut Kultury Fizycznej w Gorzowie Wlkp., Stowarzyszenie „Wspólnota Polska” Oddział w Gorzowie Wlkp., Centralne Archiwum Polonii w Orchard Lake, Gorzów Wielkopolski 2003, ss. 545. Do najbardziej nas interesujących artykułów w tejże pracy zbiorowej zaliczyć można: Dariusza Roguta Polacy z Wileniszczyzny wobozienr 108 dlajeńców wojennych i internowanych $w$ Stalingradzie (1947-1949), Adama Sudoła Wokót agresji 17 września 1939 roku i zagarnięcia kresów wschodnich Drugiej Rzeczypospolitej, Jacka TebinkiDyplomacja brytyjska wobec sprawy katyńskiej w latach 1943-1945, Mieczysława Wieliczko Dyplomacja $i$ sita. Rola Armii Czerwonej w stanowieniu ustrojów państwowych w „wyzwolonych” krajach Europy ŚrodkowoWschodniej w latach 1944-1947, Tadeusza Wolszy Historia pewnego przemówienia. Józef Stalin w ocenie gen. Wtadystawa Andersa (1953), ks. Romana Dzwonkowskiego Sytuacja duchowieństwa polskiego w ZSRR w latach 1944-1991. Na przyktadzie losów ks. Stanistawa Chodźko (1893-1978).

11. Wojciech Jasielski, Wieże z kamienia, Wydawnictwo W.A.B., Warszawa 2004, ss. 356. Jest to opowieść o Czeczenii i jej mieszkańcach oraz o toczonej od lat wojnie partyzanckiej z wielokrotnie liczniejszymi i wyposażonymi wojskami rosyjskimi. W książce przewijają się postacie, które odcisnęły swe piętno na historii tego kraju - Asłana Maschadowa i Szamila Basajewa. Autor w sposób niezwykle zajmujący opowiada o ludziach, ich zagmatwanych wojennych losach, o życiu codziennym przeplatanym „zaczystkami”. Tytułowe wieże z kamienia, to budowle stawiane dawniej na Kaukazie w celu ochrony karawan kupieckich, które z czasem stały się schronieniem kaukaskich górali i częścią ich narodowej tożsamości.

12. Rosja XX wiek. Od utopii komunistycznej do rzeczywistości globalistycznej, pod red. Julija Zołotowskiego, Wydawnictwo Uniwersytetu Jagiellońskiego, Kraków 2004, ss. 184. Praca ta przygotowana została przez rosyjskich historyków związanych m.in. z Instytutem Ekonomiczno-Prawniczym w Woroneżu i stanowi skrypt mający przybliżyć polskiemu czytelnikowi złożoną problematykę historii Rosji XX wieku, przedstawianej w zgodzie z nowymi koncepcjami współczesnej historiozofii. Autorami pracy są M. Karpaczew (rozdz. I), M. Popiel (rozdz. II), B. Tabacznikow, G. Psariow, A. Smirnow, J. Zołotowski (rozdz. III). W pracy przedstawione zostały w ujęciu chronologicznym najważniejsze wydarzenia spo- 
łeczno-ekonomiczne, polityczne i historyczne kształtujące obraz Rosji od 1905 roku po czasy współczesne. Omówiono m.in.: rewolucję 1905 roku, reformy Piotra Stołypina, gospodarkę Rosji w okresie komunistycznym oraz w czasach przemian wolnorynkowych, wojnę domową, NEP, kształtowanie się radzieckiego totalitaryzmu, źródła i istotę stalinizmu, okres II wojny światowej, destalinizację, lata „stabilizacji” breżniewowskiej, kryzys radzieckiego imperium, przemiany społeczno-polityczne za Gorbaczowa i Jelcyna, kryzys konstytucyjny i polityczny 1993 r., konflikt czeczeński, wybory prezydenckie i skomplikowaną sytuację Rosji współczesnej. Pracę kończy literatura przedmiotu.

13. Andrzej Skrzypek, Druga smuta. Zarys dziejów Rosji 1985-2004, Instytut Nauk Politycznych UW, Warszawa 2004, ss. 183. Praca ta to skryptowe ujęcie sytuacji geopolitycznej ZSRR i Rosji w okresie największych przemian zapoczątkowanych przez Michaiła Gorbaczowa, które wbrew zamysłom autora doprowadziły do rozpadu ZSRR i powstania na jego gruzach nowej formy, jaką jest Federacja Rosyjska. Autor świadomie nawiązuje w temacie do wielkiej smuty z XVII wieku, jako analogii do sytuacji w jakiej znalazło się mające trwać wiecznie radzieckie imperium. Kryzys polityczny, gospodarczy, społeczny oraz głęboki kryzys wartości dogłębnie zmienił i podzielił rosyjskie społeczeństwo na pokolenie pamiętające i tęskniące za dawną potęgą ZSRR oraz pokolenie żyjące w rzeczywistości tak odległej od „standardów” Rosji Radzieckiej, że nie potrafi w żaden sposób wyobrazić sobie nostalgii starszych za scentralizowaną gospodarką sterowaną oraz jedynowładztwem politycznym jedynie słusznej partii. Rozważania autora zaczynają się z chwilą wybrania I sekretarzem KPZR Michaiła Gorbaczowa, kończą się zaś wynikami wyborów prezydenckich z marca 2000 roku. W tych ramach chronologicznych autor prowadzi swój niezwykle interesujący wywód na temat poszukiwań przez polityków rosyjskich nowego modelu władzy i ustroju, pozwalającego powrócić krajowi do dawnej świetności.

14. Stanisława Lewandowska, Losy Wilnian. Zapis rzeczywistości okupacyjnej. Ludzie fakty, wydarzenia 1939-1945, Wydawnictwo Neriton, Instytut Historii PAN, Warszawa 2004, ss. 474. Praca jest nieco rozwiniętą i poprawioną wersją książki tejże autorki pt. Życie codzienne Wilna w latach II wojnyświatowej wydanej w 1997 r. w Instytucie Historii PAN. Składa się z trzech części. W pierwszej autorka omawia sytuację Wilna w okresie czterech okupacji: radzieckiej we wrześniu i październiku 1939 r., litewskiej od 28 października 1939 r. do 15 czerwca 1940 r., ponownie radzieckiej (w ramach Litewskiej SRR) od 15 czerwca 1940 do 22 czerwca 1941 oraz niemieckiej - do 13 lipca 1944 r. W części drugiej przedstawia kondycję ekonomiczną Wilna w okresie II wojny światowej, życie codzienne jego mieszkańców, status „prawny” Wilnian w okresie wojny oraz zagładę wileńskich Żydów. Część trzecia - to opis rozwijającego się coraz silniej po 17 września 1939 r. ruchu oporu, postaw ludności miasta wobec zmieniającej się jak w kalejdoskopie okupacyjnej rzeczywistości oraz sytuacji w mieście po jego ponownym zajęciu przez wojska radzieckie (likwidacja AK, represje, aresztowania, wysyłka do łagrów i obozów jenieckich). Pracę kończą cztery obszerne aneksy opisujące m.in. sytuację 
ludności żydowskiej w Wilnie w świetle relacji Żydów wileńskich, bibliografia oraz indeks osobowy.

15. Stanisław Ciesielski, Grzegorz Hryciuk, Aleksander Srebrakowski, Masowe deportacje ludności w Zwiqzku Radzieckim, Wydawnictwo Adam Marszałek, Toruń 2004, ss. 508. Praca ta stanowi pierwszą w polskiej historiografii próbę opisania deportacji jako ważnego narzędzia stalinowskiej polityki narodowościowej oraz gospodarczej. Jej autorzy zapisali się już w polskiej historiografii jako twórcy pracy poświęconej deportacjom ludności polskiej w głąb ZSRR w czasie II wojny światowej. Książka składa się z trzynastu rozdziałów opisujących kwestię deportacji w ujęciu problemowo-chronologicznym. Rozdział pierwszy poświęcony jest ogólnej charakterystyce deportacji w ZSRR (procedury deportacyjne, struktury organizacyjne organów przeprowadzających wysiedlenia, kategorie i status zesłańców, czas i miejsce zesłania, tryb deportacji). W rozdziale drugim przedstawione zostały pierwsze, jeszcze „nieśmiałe” akcje deportacyjne przeprowadzane przez bolszewików tuż po przejęciu władzy. W następnych rozdziałach autorzy kolejno omawiają: „kułacką zsyłkę” lat trzydziestych, oczyszczanie rejonów przygranicznych (Polacy i Niemcy z Ukrainy, Koreańczycy, Kurdowie, Irańczycy), deportacje obywateli polskich w latach 1940-1941, deportacje Ukraińców 1940-41 oraz 1944-52, wysiedlenia z Mołdawii, deportacje z republik nadbałtyckich 1941 oraz 1945-1952, deportacje Niemców nadwołżańskich w czasie II wojny światowej, deportacje narodów Kaukazu (Karaczajowie, Czeczeni, Ingusze, Bałkarzy, Kabardyjczycy), deportacje z Zakaukazia (Turcy meschetyńscy, Kurdowie, Ormianie), wysiedlenia Kałmuków 1941-1943, deportacje z Krymu w czasie II wojny światowej (Tatarzy krymscy, Bułgarzy, Grecy, Ormianie). Ostatni rozdział dotyczy represji wymierzonych w powracających do ZSRR obywateli wywiezionych na przymusowe roboty do Niemiec, bądź zbiegłych przez nacierającą Armią Czerwoną, zsyłki repatriowanych Finów, „Własowców”, ”Andersowców”, rodzin „niemieckich wspólników” i „folksdojczów”, ludności deportowanej na podstawie dekretów o uchylaniu się od pracy w rolnictwie. Pracę kończy obszerna bibliografia tematu oraz indeks osobowy.

16. Simon Sebag Montefiore, Dwór czerwonego cara, Wydawnictwo Magnum, Warszawa 2004, ss. 774. Praca ta jest pod każdym względem wyjątkowa. Po pierwsze autor postanowił w niej przedstawić Stalina nie jako bezwzględnego, żądnego krwi tyrana, lecz jako człowieka uwikłanego w zwykłe domowe sprawy: kłopoty, smutki i radości, zajmującego się dziećmi, kłócącego z żoną. Nie oznacza to jednak, że nie otrzymamy w tej książce pełnego obrazu Stalina jako polityka i dyktatora, wiecznie podejrzliwego, bezwzględnie niszczącego każdego, kogo uzna za zagrożenie dla siebie. Jednak Stalin-tyran w zestawieniu z tym samym Stalinem w domowym zaciszu bawiącym się z córką lub ukrywającym przed żoną wydaje się postacią bardziej wiarygodną, bliższą nam, co wcale nie oznacza, że bardziej ludzką. Praca ta powstała na podstawie licznych kwerend w odtajnionych w latach dziewięćdziesiątych XX wieku archiwach radzieckich (Rosyjskim Państwowym Archiwum Historii Społecznej i Politycznej, Rosyjskim Państwowym Wojennym Archiwum, Centralnym Archiwum Ministerstwa Obrony Federacji Rosyjskiej) gdzie znajdują się dokumenty i fotografie rodziny Stalina, listy Stalina, jego towarzyszy 
i ich rodzin, kremlowska księga raportów. Po drugie narracja i ujęcie chronologiczne jego życia powiązane z przełomowymi momentami w dziejach radzieckiego imperium pozwala zrozumieć jak bardzo Stalin i Rosja radziecka „stanowili jedno”. Książka składa się dziesięciu rozdziałów, posłowia, obszernej bibliografii oraz indeksu osób. Jej ogromną wartość podkreślają dotąd nie publikowane fotografie pokazujące życie codzienne Stalina.

17. Arno Lustiger, Czerwona ksiega. Stalin $i$ Żydzi. Tragiczna historia Żydowskiego Komitetu Antyfaszystowskiego i radzieckich Żydów, Wydawnictwo W.A.B., Warszawa 2004, ss. 537. Praca ta, to próba poznania źródeł rosyjskiego, a następnie radzieckiego antysemityzmu oraz pokazania, jak dziwne były wzajemne stosunki pomiędzy radzieckimi Żydami, bardzo często bezgranicznie poświęcającymi się dla ojczyzny światowego proletariatu, a ową ojczyzną, pałającą coraz silniejszą nienawiścią do wszystkiego, co żydowskie (języka, kultury), niszczącą po wojnie żydowskie instytucje kulturalne i społeczne oraz wyznaniowe. Lustiger stara się dociec, co takiego spowodowało, że zainicjowano „sprawę lekarzy kremlowskich" oraz przygotowywano się do zdecydowanej akcji mającej wyrzucić społeczność żydowską za ramy radzieckiego społeczeństwa. Książka składa się z dwóch części. W pierwszej autor przedstawia dzieje Żydów rosyjskich: dyskryminację za carów, pierwsze próby ich asymilacji, rolę Żydów w rosyjskiej polityce przed rewolucją październikową, zmianę sytuacji ludności żydowskiej po wygranej bolszewików, ich egzystencję w warunkach dyktatury proletariatu, powstanie i rozwój Żydowskiego Okręgu Autonomicznego w Birobidżanie, narastającą falę antysemityzmu w okresie stalinowskiego terroru, pomoc ZSRR przy narodzinach Izraela oraz nasilenie się po tym fakcie antysyjonizmu, narastanie wojny państwa radzieckiego z Żydami aż do otwartego wystąpienia przeciwko nim w czasie kampanii przeciwko „kosmopolitom bez korzeni”. Bardzo obszernie omówił on także powstanie, rozwój, działalność (zarówno w ZSRR, jak i poza jego granicami) oraz brutalną likwidację Żydowskiego Komitetu Antyfaszystowskiego. W części tej omówiono losy Żydów w krajach obozu socjalistycznego, gdzie także narastał zdaniem autora - podsycany wydarzeniami w ZSRR antysemityzm (Niemcy, Czechosłowacja, Polska). Na koniec autor pokazuje zmiany, jakie zaszły w Związku Radzieckim oraz Rosji do dnia dzisiejszego: narodowy i emigracyjnych ruch Żydów, walkę o prawo do emigracji, Miejsce Żydów w czasach pierestrojki oraz zupełny ewenement - powstanie Antysyjonistycznego Komitetu Społeczeństwa Radzieckiego. W części drugiej zamieszczono noty biograficzne najwybitniejszych działaczy żydowskich w ZSRR na przestrzeni ostatnich 100 lat. Pracę kończy bibliografia selektywna oraz indeks osób.

18. Czesław Grzelak, Wojenna edukacja kadr Wojska Polskiego na froncie wschodnim 1943-1945, Wydawnictwo Neriton, Warszawa 2004, ss. 303. Jest to jedna z pierwszych prac historycznych poruszających dotychczas mało zbadany problem kształcenia kadr oficerskich i podoficerskich dla potrzeb Armii Polskiej w ZSRR w okresie wojny poprzez organizację szkół i kursów, ich kadrę, realizację procesu dydaktycznego oraz jego efekty zauważalne bezpośrednio na polu walki. Książka składa się z sześciu rozdziałów. W pierwszym Cz. Grzelak omawia kształ- 
cenie kadr w Polskich Siłach Zbrojnych w ZSRR w okresie od maja 1943 do lipca 1944. W drugim potrzeby i uzupełnianie kadr w Wojsku Polskim w latach 1944-1945, w trzecim kształcenie kadr oficerskich, w czwartym - kadr podoficerskich. W rozdziale piątym znalazły się informacje o kształceniu polskich kadr w szkołach oficerskich i podoficerskich Armii Czerwonej, w rozdziale szóstym o doskonaleniu kadr w Wojsku Polskim. Pracę kończy bibliografia tematu oraz indeksy: miejscowości i osobowy.

19. Krzysztof Buchowski, Panowie $i \dot{z}$ mogusy. Stosunki polsko-litewskie w międzywojennych karykaturach, Instytut Historii Uniwersytetu w Białymstoku, Białystok 2004, ss. 263. Głównym celem tej książki jest prezentacja polskich i litewskich rysunków satyrycznych oraz karykatur publikowanych w okresie międzywojennym na łamach czasopism, a dotyczących niezwykle skomplikowanych i napiętych wzajemnych relacji polsko-litewskich w okresie międzywojennym. Większość rysunków jest „gorącym” komentarzem przeróżnych wydarzeń, którymi interesował się ówczesny czytelnik i obywatel każdej z „obmalowywanych” stron. Książka składa się z trzech zasadniczych części. W pierwszej autor przedstawia nam w ogromnym skrócie sytuację polityczną oraz klimat, jaki panował wówczas we wzajemnych polsko-litewskich relacjach, charakteryzując przeróżne postawy polskich „panów” i litewskich „żmogusów”. Część druga - to zbiór 130 satyrycznych rysunków polskich, głównie z „Muchy”, „Szpilek”, „Ilustrowanego Kuriera Codziennego” i „Cyrulika Warszawskiego”. Część trzecia to analogiczne zestawienie 79 prac litewskich, zamieszczanych głównie w „Kuntaplis”, Trymitas”, „Kuntapliava”, „Sekmadienis”, „Ragutis” i „Garnys”. Pracę zamyka bibliografia selektywna tematu oraz indeks nazwisk.

20. Repatriacje i migracje ludności pogranicza w XX wieku. Stan badań oraz źródta do dziejów pogranicza polsko-litewsko-biatoruskiego, red. Marek Kietliński i Wojciech Śleszyński, Archiwum Państwowe w Białymstoku, Instytut Historii Uniwersytetu w Białymstoku, Białystok 2004, ss. 292. Książka stanowi podsumowanie konferencji pod tym samym tytułem, która odbyła się w 2003 r. w ramach projektu „Wspólne dziedzictwo ziem północno-wschodnich II Rzeczypospolitej”. Jest to trzecia publikacja pokonferencyjna ukazująca się w ramach tej serii. Do najbardziej interesujących nas artykułów zaliczyć z pewnością można tekst Algisa Kasperavicius Ucieczka Litwinów i Żydów z krajukłajpedzkiego w 1939 r. podczas zagarnięcia go przez III Rzeszę, Jolanty Szczygieł-Rogowskiej Repatriacja ludności polskiej z obwodupawtodarskiego do Polski w 1946 roku w świetle tzw. księgi pawtodarskiej znajdujacej się w zbiorach Muzeum Historycznego w Biatymstoku, Daniela Boćkowskiego Źródła do problemu ruchów migracyjnych na ziemiach pótnocno-wschodniej Polski w czasie II wojny światowej, Krzysztofa Buchowskiego Uwagi o tak zwanych repatriacjach ludności polskiej z terenów Litwy etnicznej w latach 1945-1947, Eugeniusza Mironowicza Przesiedlenia ludności polskiej z Białorusi w latach 1944-1946, Edmunda Jarmusika Źródła historyczne katolicyzmu na Biatorusi (czasy powojenne) w zbiorach Państwowego Archiwum Federacji Rosyjskiej. 
21. Polska i jej wschodni sqsiedzi wXX wieku. Studia i materiaty of iarowane prof. dr: hab. Michatowi Gnatowskiemu w 70-lecie urodzin, red. naukowa Hanna Konopka, Daniel Boćkowski, Wydawnictwo Uniwersytetu w Białymstoku, Białystok 2004, ss. 478. Książka ta jest zbiorem studiów poświęconych szeroko rozumianym sprawom wschodnim. Tworzy ją 39 artykułów podzielonych na trzy działy: Polska i jej wschodni sąsiedzi 1914-1939, Pod dwiema okupacjami 1939-1945, Okres powojenny. Dojej tworzenia zaproszono historyków młodego pokolenia z wielu ośrodków akademickich w Polsce. Wśród artykułów godnych polecenia znajdują się następujące teksty bezpośrednio odnoszące się do naszej tematyki: Joanny Gierowskiej-Kałłaur Wtadza sadownicza na terenie bytego Wielkiego Księstwa Litewskiego w czasach Zarzadu Cywilnego Ziem wschodnich (1919-1920), Grzegorza Zackiewcza Zapomniana karta polskiej sowietologii - biuletyn „Rosja sowiecka" (1931-1936), Czesława Grzelaka Rola Armii Czerwonej w wyborach na zajętym terytorium Polski pótnocno-wschodniej w 1939 roku, Mieczysława Wieliczko Sowiecko-niemiecka wymiana żotnierzy Wojska Polskiego jesienia 1939 roku, Daniela Boćkowskiego Radzieckie starania o poprawe sytuacji aprowizacyjnej obwodu biatostockiego w latach 1939- 1941, Piotra Kołakowskiego Sowiecki aparat bezpieczeństwa wobec podziemia polskiego na Kresach Wschodnich 1939-1941. Zarys problematyki, Andrzeja Pepłońskiego Funkcjonowanie wywiadu Komendy Gtównej ZWZ-AK na zapleczu frontu wschodniego, Krzysztofa Buchowskiego Litwa wobec ludności polskiej od września 1939 do czerwca 1941, Macieja Szczurowskiego Rzad $i$ spoteczeństwo Litwy wobec internowania Polaków w latach 1939-1940, Wandy Krystyny Roman Geneza polskiej konspiracji wojskowej na Wileńszczyźnie w latach II wojny światowej, Grzegorza Hryciuka Zmiany liczebności ludności Wotynia podczas okupacji radzieckiej w latach 1939-1941, Beaty Szubtarskiej Z dziatalności interwencyjnej Ambasady RP w ZSRR w latach 1941-1943, Dariusza Roguta Polsko-sowieckie rozmowy dyplomatyczne w sprawie zwalniania z obozów Polaków i obywateli polskich $z$ Wileńszczyzny (1945-1948), Dariusza Matelskiego Restytucja polskich dóbr kultury $w$ prawodawstwie międzynarodowym i uktadach Polski z sasiadami, Eugeniusza Mironowicza Polskie i biatoruskie drogi do niepodlegtości (1945-2000). Książka zawiera pełną bibliografię prac prof. Michała Gnatowskiego za lata 1975-2004.

22. Pokolenia spetnionego obowiązku. Studia z dziejów Polski i Polaków w kraju i na obczyźnie $w$ XX wieku dedykowane Profesorowi Józefowi Garlińskiemu, pod red. Janusza Farysia, Romana Nira i Marka Szczerbińskiego, Centralne Archiwum Polonii w Orchard Lake, Innstytut Historii Uniwersytetu Szczecińskiego, Zamiejscowy Wydział Kultury Fizycznej poznańskiej AWF w Gorzowie Wlkp., Gorzów Wlkp. 2004, ss. 469. Książkę tworzą 32 artykuły podzielone na trzy działy: Z dziejów Polski i Polaków w kraju i na obczyźnie, Z zagadnień międzynarodowych, Varia. Do najbardziej interesujących nas artykułów zawartych w tej pracy zbiorowej zaliczyć można: Daniela Boćkowskiego Kolaboracja ludności żydowskiej z wtadza radziecka na Białostocczyźnie w latach 1939-1941. Prawdy i mity, Marii Kalczyńskiej Polacy w Rosji. Historia i dzień dzisiejszy. (Wybrane 
wq̨tki z obecności Polaków w ST. Petersburgu), Jacka Reginia-Zacharskiego Brytyjsk a pomoc dla armii ochotniczej w 1919 roku a kwestia niepodlegtości Ukrainy, Roberta Łosia Polityka Republiki Federalnej Niemiec wobec Zwiqzku Radzieckiego w ostatnim okresie rzqdów kanclerza Konrada Adenauera (1947-1954). Pracę kończą notki o autorach.

23. Nadzieja, ztudzenia, rzeczywistośé. Studia z historii Polski XX wieku. Ksiega dedykowana Profesorowi Tadeuszowi Wyrwie, pod red. Wiesława Hładkiewicza i Marka Szczerbińskiego, Centralne Archiwum Polonii w Orchard Lake, Instytut Politologii Uniwersytetu Zielonogórskiego, Zamiejscowy Wydział Kultury Fizycznej poznańskiej AWF w Gorzowie Wlkp., Archiwum Państwowe Oddział w Gorzowie Wlkp., Gorzów Wlkp. 2004, ss. 550. Książkę tworzą 42 artykuły podzielone na trzy działy: Najnowsze dzieje Polski, Dzieje emigracji i Polonii, Varia. Do najbardziej interesujących nas artykułów zawartych w tej pracy zbiorowej zaliczyć można: Adama Koseskiego Formowanie polskich jednostek wojskowych w ZSRR (1943-1945), Sławomira M. Nowinowskiego Likwidacja Poselstwa RP w Rydze w roku 1939, Wacława Łęckiego Ludobójstwo Polaków na Wołyniu w latach 1939-1945, Tadeusza P. Rutkowskiego Rzqd RP na uchodźstwie (1939-1945) a sowieckie stużby wywiadowcze, Daniela Boćkowskiego Rada Narodowa RP na uchodźstwie wobec Polaków w ZSRR w latach 1939-1945. Zarys problematyki. Pracę kończą notki o autorach. 